\title{
Humanitarian interventions: a critical approach ${ }^{*}$
}

Fernando José Ludwig ${ }^{1}$

\section{Abstract}

This paper aims to confront the manifold aspects of "humanitarian" intervention along with the conceptualization of national sovereignty. It is argued that, among the many forms of humanitarian interventions (such as sanctions, material assistance, aid, etc.), military intervention should always be the last resort when it comes to guaranteeing both the protection of human rights and regional stability. The discussion about intervention in a sovereign state has long been an inherently part of international studies. On one hand we have the Westphalian concept of sovereignty (therefore, the state-centrism perspective and the absolute rejection of external intervention without consent), and on the other hand, the consolidation of the concept of human rights, advocating that interventions are necessary where human abuses are practised. Merging them in order to verify the legitimacy of humanitarian intervention in a contemporary world has been the real challenge to many scholars in the field. It is argued that humanitarian intervention has very often been used as a fundamental key to serve transnational elites (within developed countries) to impose their universal values. In spite of this, it is imperative to bear in mind the multifarious aspects of conflictuality and humanitarian interventions in the light of the past experiences and future challenges.

Keywords: Humanitarian interventions. Sovereignty. Liberal peace. Humanitarian imperialism.

* Recebido em 26.04.2010

Aprovado em 24.05.2010

1 First Degree of International Relations (University of Coimbra, Portugal) in 2007; Master Degree of International Relations (University of Kent at Canterbury, United Kingdom) in 2008; Phd Candidate of International Politics and Conflict Resolution at the University of Coimbra / Social Science Centre - Portugal.

e-mail: fernandoludwing@ces.uc.pt 


\section{Introduction}

The international system has been and still is in a constant evolution, especially in the $20^{\text {th }}$ and $21^{\text {st }}$ centuries, bringing old and new dilemmas and challenges that are nowadays inherently part of international relations discussions. Similarly, the dilemma between intervention and sovereignty related to humanitarianism is one of the main debates among international relations scholars. During the 20th century, the international system's evolution, along with International Relations development as a discipline itself, brought new paradigms that should be considered regarding debates about the imposition / exportation of peace (liberal) versus the concept of imperialism.

So the major goal of this paper is to discuss the following research question: is there, beyond the altruistic and humanitarian discourse that is very often used to justify humanitarian interventions, a way to achieve global governance (or, at least, values exportation) by developed countries? In attempting to reach a reasonable answer, this paper will first look at the moral and ethical implications related to the manifold aspects of international humanitarian interventions, when claimed to be universal. With respect to this, following the same line of thought, it is imperative to confront the concept of humanitarian intervention with the conceptualization of state sovereignty, and we therefore intend to explore the possible interpretations, in theoretical terms, alluding to the topic of humanitarian intervention and its legal components within the present international system. Secondly, we want to explore the ways in which humanitarian interventions contribute practically to the construction of a plausible liberal global peace.

This paper has been structured to fulfil its ontological purpose, that is, to ascertain whether humanitarian intervention is being used as an instrument to export Northern values and structures in order to bring a liberal peace. So, in order to find a reasonable explanation for humanitarian intervention's role within the international system, we propose to divide the present work into two main parts. First, naturally, is a discussion of the main arguments that support humanitarian intervention in terms of its moral and ethical justification. Second, a critical approach regarding the concept of liberal peace expansion and implementation, normally justified as being universal, will be presented. Finally, some conclusions 
will be drawn in relation to the main argument of this paper, which is to stress the difficulty in establishing a causal nexus between the right to interfere and the effective protection of "universal" human rights. Consequently, as we shall explore better during this paper, is fair to assume that the great majority of instances of humanitarian intervention in the $21^{\text {st }}$ century are selected and conditioned by developed countries in order to export values and forms of governance: what Chomsky calls "humanitarian imperialism".

\section{Humanitarian intervention, morality and legality}

Throughout the history of international relations the question of state sovereignty (in the modern meaning of the term) has been a core issue within the configuration of the international system. The historic moment generally taken to mark the implementation of this new era - sovereignty for international relations is characterized by the signing of the Treaties of Westphalia in 1648, were the ultimate aim of which was to bring lasting peace to Europe. Basically, these two treaties have inserted two fundamental principles that had an enormous impact over states' conduct of foreign policies. First, the notion where the state accomplished a full independence in relation to the Catholic church (that is, state laicization); and second, and more importantly for this paper, was the introduction of an essential praxis that repressed any external intervention within a state's domestic politics (e.g., the concept of sovereignty). The juxtaposition of these two concepts in the centre of international relations practice transformed the world order at the time, clearly state-centric (CRAVINHO, 2002, p. 61-62), and still plays an important role today. It is this concept of sovereignty, derived from the Westphalian order, that we intend to explore.

In spite of this, due the impossibility of talking about intervention (of any kind: humanitarian, military, economic, etc.) without at least considering the basic premises of sovereignty, this section first aims to explore the theoretical foundations that support or reject the concept of sovereignty; later it assesses the moral and ethical justifications that it are used in the name of common universal right, so called humanitarianism; and finally, it explores the ways in which these 
discussions have an impact on the formation of international law nowadays, that is, to see whether is legal to abandon the secular concept of sovereignty and replace it with intervention.

It is evident that the question of whether the intervention is a universal common right is not in fact a recent topic for discussion. Thus Sowell, in 1939, reports the possibility of intervention using force, contrary to the principle of sovereignty, as he puts it.

According to the generally accepted doctrine of international law, no state has a right to interfere in the internal affair of a sister state, and the application is pushed so far as to forbid any attempt to check brutality and inhumane treatment in another state of that state's own nationals. Yet this doctrine, alleged to be a fundamental principal of international law, fails by the test that it does not tend to keep the peace (STOWELL, 1939, p. 733-734).

And he goes on, advocating the reasons why intervention becomes not a right, but instead a duty of the international community,

When, however, the conduct of a state, not excused by some untoward event like revolution or civil war, constitutes, on the part of the responsible government a deliberate violation of that minimum of security and justice to which every individual in a civilized community is entitled, it becomes the right and the duty of others states to intervene in so far as is practicable to prevent or lessen such severities. (STOWELL, 1939)

Thus a moral reason is invoked that is superior to any type of social organization or international norm that allows, in the absence of this level of security and justice, any state or international organization the right to intervene. It is exactly in that point that the paradoxical essence of the humanitarian intervention rhetoric proposed by this paper is concentrated.

This question has already been discussed within international relations along with its development as a discipline during the $20^{\text {th }}$ century, as mentioned earlier. On the one hand, for the defenders of an international community's right or duty to intervene it is undoubtedly necessary to consider the universality of human rights. 
However, to decide between the universality and the relativity of human rights (e.g., Western human rights) per se would be at least questionable, and so we assume the relativity position, but a deep analysis of this theme is beyond the purpose of this paper. In fact, what is really crucial to understand is whether the justifications and the reasons that lead to intervention in the name of a "humanitarian" universal right it are valid, theoretically and empirically. Thus, concerning the theoretical approach, Baggini - in his search to find the moral within rationality - presents what he calls the weak and strong altruism. Where the weak altruism is characterized by a person (or, in this case, certain groups or states) who is "naturally inclined to care about the interests of others" (BAGGINI, 2002, p. 447) and delimitates its actions accordingly. On the other hand, strong altruism is marked by a person (groups or states) who "recognizes the interests of others as a valid reason for acting even in cases where he has no such inclination to act" (BAGGINI, 2002, p. 448). Transposing these two distinct concepts that characterize individuals' or groups' moral reasons of humanity to the international level, and, more specifically, to the humanitarian intervention field, necessarily requires a rethink about the current motives that drive international organizations (mostly conducted by the United Nations and NATO) and developed powers to intervene. It is fair to say, bearing in mind the recent history of international relations, that in the search of the strongly altruistic states (or international organizations) would they be more prone to act even in those cases where they were not willing or inclined to do it?

In relation to this, Wheeler posed the following starting question in his argument "what moral value attaches to the rule of sovereignty and non-intervention if they provide a licence for governments to violate global humanitarian standards?" (2003, p. 27). Thus, according to the realist theory, when states' vital interests are at stake, humanitarian intervention is no more than a question of maintaining or increasing their status quo within the international system (in terms of balance of power). That is, when humanitarian intervention does not represent any kind of substantial gain (economically, politically, geographically) states would not be wiling to risk their soldiers' lives, or even to bear the inherent cost of such action, as Wheeler points out. 
but states will not use force unless they judge vital interests to be at stake. Thus, the best we can hope for is a happy coincidence when the promotion of national security also defends human rights (WHEELER, 2003, p. 30).

Probably the most important aspect that plays in favour of the realism tradition is based on the practice of selectionism by this type of humanitarian intervention. That is, there is an expressive lack of consensus in clearly determining the motives and/or justifications that lead to intervention. Consequently, what frequently happens at the centre of the international community is that the very same argument used to justify one intervention may not necessarily be applied in other cases (arguments such as political regime, human rights, justice, etc.), which supports the realist argument that the moral is, in these cases, an instrument of power.

On the other hand, the same author presents a views - solidarist theory - contrary to the realist interpretation of humanitarian intervention as being a simple product of power relations. According to this point of view, which coincides with the author's argument, there are minimum requirements that could confer on foreign states the right of intervention. Whilst in the realist tradition there is no room for intervention, e.g., absolute respect for the concept of sovereignty, in the solidarist theory humanitarian intervention would be endowed with legality within the international community.

Thus, in these cases, in order to verify that legitimacy in the international community the intervention must fulfil four compulsory requirements. In the first place, the existence of a "just cause" is necessary, even if the immediate outcome of this cause results in war. In spite of this, Ramsbotham stressed that the major difference between traditional wars and just wars is that the use of force in the former relies upon the defence of international norms, such as decolonization (East Timor), democracy (Sierra Leone), conflict resolution norms (Democratic Republic of the Congo), humanitarian norms (Kosovo) and, finally, anti-terrorist norms (Afghanistan) (RAMSBOTHAM et al, 2005, p. 285).

Secondly, the use of force must be the last resort. Thirdly, it is necessary to apply the proportionality principle and, finally, the great likelihood of success is imperative if intervention is the best option (WHEELER, 2003, p. 34). 
Between the legality and illegality of humanitarian intervention, between the view of realists and solidarists, what is taken for granted is the fact that there is no consensus among international relations scholars about this problem. But, where is the productivity in analysing these questions? Since it is impossible to formulate universal "recipes" to legitimise the use of humanitarian interventions, what we want to do here is to stress the fact that there is a set of interests behind the use of humanitarianism. Are these arguments destined to search for a liberal peace or an instrument of $21^{\text {st }}$ century "humanitarian imperialism"? These questions will be addressed in the next section.

\section{Liberal peace, humanitarian intervention and imperialism}

After the end of the cold war humanitarian interventions, through peacekeeping missions, witnessed a boom of unprecedented proportions. The immediate consequence of this was the standardization of these peace missions. Although, by no means disregarding the idealist/solidarist point of view, we suggest that such models/patterns are based on the imposition/exportation of values that are currently claimed to be "universal", which very often represent the developed countries' self-interest. It is under the aegis of this argument that the present section aims to explore the link between liberal peace, imperialism and the reasons invoked nowadays in the name of the common good of humanity.

And so the enormous conceptualizations and acceptations of peace make it hard to present one single definition, and it is therefore hard to answer the simple question formulated by Richmond (2008, p. 7): what is peace?. Probably the most accurate answer to this question would be "it depends", that is, it depends where, or what you want to analyse, explore or identify. Since ancient times ( the Roman, Jewish or Christian peace) to the present notion of the term, the concept of peace has taken values that not only served its final objective (e.g., the absence of conflict), but also justified certain international actors' behaviour, both internally and externally. So we aim to understand the arguments that lead to the choice of humanitarian intervention in the circumstances of the present international system. 
Thus, the liberal peace, as described by Mandelbaum (2002, p. 6), is the result of a combination of peace, democracy and free markets. Duffield (2001, p. 10-11) also says that "the idea of liberal peace, for example, combines and conflates 'liberal' (as in contemporary liberal economic and political tenets) with 'peace' (the present policy predilection towards conflict resolution and societal reconstruction)". It is worth to stressing the fact that one element of liberal peace (in this case, democracy) is also a requirement used to justify the reasons for intervention, as mentioned in relation to Wheeler's position, in the previous section. Nevertheless, as with the policies presented by international institutions (particularly financial ones), liberal premises claim that an ideal society can be achieved - one free of the scourges of poverty, war, social and political dysfunctions, etc. - if their stipulations are followed to the letter. As Richmond puts it:

The liberal peace provides the 9good life' if its formulas are followed, for all, and without exception, and even if rests on a coercive introduction through invasion or peace enforcement" (RICHMOND, 2008, p. 13).

Meanwhile, it is known that such a suggestion, that is, the guarantee of prosperity, in the great majority of humanitarian interventions, does not match up to reality. In fact, the conditions imposed by international organizations (democracy, free-market, structural adjustments, etc.) are developed to serve a specific pre-determined group (elites) of a transnational society (mostly based in the developed countries).

But can we relate the liberal peace premises and the new imperialism? Here, Richmond argues,

The notion of peace that emerges is bounded, spatial and temporally limited within specific states. It represents a victor's peace, founded upon the use of force and a form of imperialism. Imperialism gradually became a key part of a realist notion of peace (and contributed to the later development of the liberal peace) (RICHMOND, 2008, p. 45).

Well, taking the above realist view of peace as a temporal/spatial product of a specific group of victorious nations designed to defend their interests, the reasons that justify humanitarian intervention may be understood as an instrument of 
global governance, which aims to influence, through the standardization of values, the behaviour of states in crisis. In relation to this, Chomsky (2008) presents the concept of "humanitarian imperialism", which is also defended in this paper. The major point here is to question the "noble" (or altruistic) phase of international policies, as practised by the world powers (specifically by the United States of America) after the end of the Cold War. This author basically analyzes, from the ouside, US foreign policy and the North Atlantic Treaty Organization's (NATO) actions from the end of World War II until the recent past in order to highlight values that are claimed to be altruistic (weak altruism), such as human rights, democracy, terrorism, etc. The major goal of his analysis, as I see it, is to distinguish the individual interests of each state (or group of states) found in political discourse from political practice. Questioning whether the term humanitarian intervention exists or not, as he observes:

We might ask finally whether humanitarian intervention even exists. There is no shortage of evidence that it does. The evidence falls into two categories. The first is declarations of leaders. It is all too easy to demonstrate that virtually every resort to force is justified by elevated rhetoric about noble humanitarian intentions... (CHOMSKY, 2008, p. 48).

"The second category of evidence consists of military intervention that had benign effects, whatever its motives". (CHOMSKY, 2008, p. 48).

We have tried to sketch the major arguments that justify, or not, humanitarian intervention in relation to a certain number of conditionalities. We also have argued that the premises used to justify the intervention as presented by the international actors (in this case, states and international organizations) serve individual interests. This reasoning is based on a critical view of international relations. According to Robert Cox (1993, p. 62), one of the mechanisms responsible for imposing common universal values is expressed in the formation and operation of international organizations, because they are: imbued with values that facilitate the expansion of the present hegemonic order; they are themselves a product of this hegemonic world order; they ideologically legitimate the norms of the world order; they co-opt the elites from peripheral countries and; they absorb counter-hegemonic ideas. Finally, following the arguments mentioned above, it 
really is plausible to affirm that this vision of world politics leads to thinking that the argument of liberal peace is nothing but a conditioned peace enforced by the a restricted number of developed countries (led, what is more, by the US), who thus define their own rules and justifications to support their actions.

\section{Conclusion}

In this paper we have outlined the major arguments that support the divorce between discourse and political practice in world politics, to expose the real interests that lead to humanitarian interventions around the world. Which is to say, political discourse is nowadays characterized by a weak altruism, which serves as a form of global governance. Another important point that deserves some attention is that there is an empirically verifiable series of factors that weakens the validation of a humanitarian intervention solidarist theory. On the one hand, the first is related to the lack of consensus or equity in the reasons and/or justifications that lead to an intervention; for example, Iraq, Afghanistan, Kosovo, etc, had quite distinct motivations. On the other hand, except on rare occasions, it would be a naive analysis that defends or advocates the existence of any type of proportionality, where military force is used as the last resort, even knowing that there is a high probability of success, leading to some kind of resolution. We thus conclude that, morally and ethically, humanitarian intervention is overwhelmingly used as an instrument of domination and the exportation of values.

Furthermore, the discussion about the liberal peace premises, humanitarian intervention and (new) imperialism follows the very same path of the previous argument. That is, while liberal peace is a victor's peace, which is sustained by values formulated by the developed countries, humanitarian intervention (conducted by states and international organizations) is an instrument used by a transnational capitalist class whose major objective is the maintenance of the present international order. In other words, we agree with Chomsky's interpretation of humanitarian intervention, where the term is used to sell wars and defend individual interests. 


\section{Intervenções humanitárias: uma aproximação critica}

\section{Resumo}

O presente trabalho visa analisar os distintos aspectos das intervenções "humanitárias" em conjunto com a conceitualização da soberania nacional. Diante das diferentes formas de intervenções humanitárias (como sanções, assistência material, ajuda etc.), é argumentado aqui que intervenções - nomeadamente militares - devem sempre ser utilizadas como sendo último recurso quando se pretende garantir tanto a proteção dos direitos humanos quanto a estabilidade regional/local. Há muito que se discute, tanto em termos teóricos quanto práticos, entre a soberania e a intervenção no seio das Relações Internacionais. Por um lado, o conceito secular de soberania, que deriva dos tratados de Westphfália (estatocêntrico e absolutamente contra qualquer tipo de intervenção nos assuntos internos dos Estados) seguido, por outro lado, da consolidação gradual de direitos humanos "universais" que, por sua vez, advoga o dever de se intervir quando se verifica abusos dos direitos humanos. A tentativa de fundir ambos os conceitos a fim de verificar a legitimidade das intervenções humanitárias no mundo contemporâneo tem sido um grande desafio para pesquisadores em todo o mundo, Finalmente, o presente paper argumenta que muitas vezes o termo intervenção humanitária é usado como sendo um fator fundamental para defender interesses de uma elite transnacional comum (localizada no seio dos países desenvolvidos) e impor seus valores universais - tais como, democracia, abertura de mercados, etc.

Palavras-chave: Intervenções humanitárias. Soberania. Paz liberal. Imperialismo humanitário.

\section{Bibliography}

BAGGINI, Julian. Morality as a rational requirement. In Philosophy, v. 77, p. 447$453,2002$.

CHOMSKY, Noam, Humanitarian Imperialism: the new doctrine of imperial right. In Monthly Review, p. 22-50, Sept., 2008. 
COX, Robert W. Gramsci, hegemony and international relations: an essay in method. In: GILL, Stephen (Ed.). Gramsci, historical materialism and international relations. Cambridge: Cambridge University Press, 1993. p. 49-66.

CRAVINHO, João Gomes. Visões do mundo: as relações internacionais e o mundo contemporâneo. Lisboa: Imprensa das Ciências Sociais, 2002.

DUFFIELD, Mark. Global governance and the new wars: the merging of development and security. London: Zed Books, 2001.

MANDELBAUM, Michael. The ideas that conquered the world. New York: Public Affairs, 2002.

RAMSBOTHAM, Oliver et al. Contemporary conflict resolution, Cambridge: Policy Press, 2005.

RICHMOND, Oliver. The problem of peace: understanding the liberal peace. In conflict, security and development, v. 6, n. 3, p. 291-314, 2006.

RICHMOND, Oliver P. The transformation of peace. New York: Palgrave, 2007.

RICHMOND, Oliver P. Peace in international relations. New York: Routledge, 2008.

STOWELL, Ellery C. Humanitarian Intervention. In the american journal of international law, v. 33, n. 4, p. 733-736, 1939.

WEBER, Cynthia. Simulating sovereignty: intervention, the state, and symbolic exchange, Cambridge: Cambridge University Press, 1995.

WHEELER, Nicolas J. Saving Strangers, humanitarian intervention in international society, Oxford: Oxford University Press, 2003. 